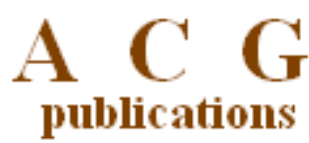

Rec. Nat. Prod. 11:4 (2017) 334-344

records of natural

products

\title{
Cytotoxic Cardenolides from Calotropis Species: A Short Review
}

\author{
Eric Wei Chiang Chan ${ }^{* 1}$, Nuha I. Sweidan ${ }^{2}$, \\ Siu Kuin Wong ${ }^{3}$ and Hung Tuck Chan ${ }^{4}$
}

\author{
${ }^{1}$ Faculty of Applied Sciences, UCSI University, Cheras 56000, Kuala Lumpur, Malaysia \\ ${ }^{2}$ Department of Chemistry, University of Petra, Amman 961343, Jordan \\ ${ }^{3}$ School of Science, Monash University Sunway, Petaling Jaya 46150, Selangor, Malaysia \\ ${ }^{4}$ Secretariat, International Society for Mangrove Ecosystems, c/o Faculty of Agriculture, \\ University of the Ryukyus, Okinawa 903-0129, Japan
}

(Received January 03, 2017; Revised March 01, 2017; Accepted March 07, 2017)

\begin{abstract}
From different plant parts of Calotropis species (C. gigantea and C. procera), various classes of compounds such as oxypregnanes, terpenoids, sterols, cardenolides and flavonoids have been isolated. Of these compounds, the cardenolides stand out as many of them have anticancer properties. Cardenolides are $\mathrm{C}_{23}$ steroids with a five-membered unsaturated butyrolactone ring consisting of a steroid nucleus, a lactone moiety at C-17 and a sugar moiety at C-3. The roles of cardenolides in the treatment of human cancer have been established as they can induce apoptosis and inhibit the growth of cancer cells. Structure-activity relationship analyses have yielded some interesting findings on their cytotoxicity. Compounds with six-membered ring sugar groups generally have significantly stronger inhibitory activity than those with five-membered ring sugar groups. A formyl or methyl-hydroxyl group at C-10 enhances cytotoxicity while the presence of a $4^{\prime}-\mathrm{OH}$ or $16-\mathrm{OH}$ group decreases cytotoxicity. Chemical modification of 2"-oxovoruscharin, a novel cardenolide extracted from the root bark of $C$. procera, has led to the synthesis of UNBS1450. The compound is characterized by more potent antiproliferative activity, lower toxicity, and is a strong sodium pump inhibitor and inducer of non-apoptotic cell death. UNBS1450 is currently in Phase I clinical trials.
\end{abstract}

Keywords: Calotropis gigantea; Calotropis procera; cytotoxicity; structure-activity relationship. (C) 2017 ACG Publications. All rights reserved.

\section{Introduction}

Calotropis of the family Apocynaceae (Asclepiadaceae) is a small genus of three species with accepted names [1]. They are Calotropis gigantea (L.) Dryand. (syn. Asclepias gigantea), Calotropis procera (Aiton) Dryand. (syn. Asclepias procera) and Calotropis acia Buch. Ham. (syn. Asclepias herbacea and Madorius acia). These species are shrubs or small trees (3-4 m tall) with multiple stems and produce copious milky latex [2]. Leaves are opposite, thick, fleshy, broad and woolly underneath. Flowers are white and have five fleshy lobes with tips that are pale lilac in $C$. gigantea and purple violet in $C$. procera (Figure 1). Fruits are a fleshy aggregate with a pointed tip and seeds are ovoid with an apical tuft of white silky hairs. The two species are fast-growing and they flower throughout the year. Both $C$. gigantea and $C$. procera occur naturally from Africa to South and Southeast Asia including southern China while C. acia is restricted to India, Bangladesh and Nepal in South Asia [2].

\footnotetext{
* Corresponding author: E-Mail: erchan@yahoo.com; Phone: +603 9101 8880; Fax: +603 91023606.
} 

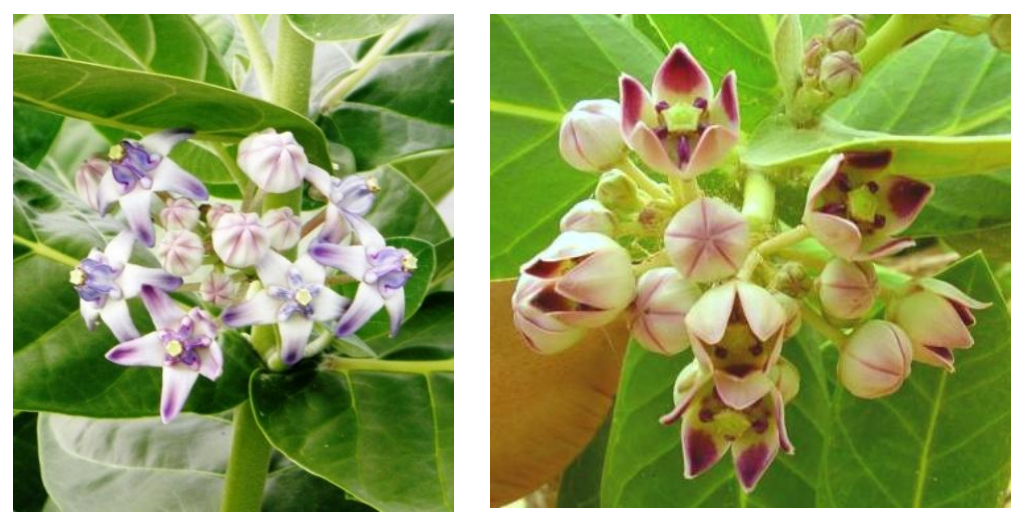

Figure 1. Flowers of Calotropis gigantea (left) and Calotropis procera (right).

From the many reviews on Calotropis species [3], C. gigantea [4-7] and C. procera [9-18], their uses in traditional medicine are so multifarious that all plant parts including the latex are remedy for many kinds of ailments and infections. A literature review on different plant parts of $C$. procera reported as many as 77 ethno-medicinal uses, notably, latex (27), leaves (19) and roots (10) [19]. The scientific evidence of some of these uses requires validation.

\section{Phytochemistry}

The chemical constituents of $C$. gigantea and $C$. procera have been extensively investigated, leading to the isolation of many oxypregnanes, terpenoids, sterols, cardenolides and flavonoids (Table 1). Of these classes of compounds, the cardenolides are outstanding in that many have anticancer properties by being cytotoxic to human cancer cells. Afroside, calactin, calotoxin, calotropagenin,

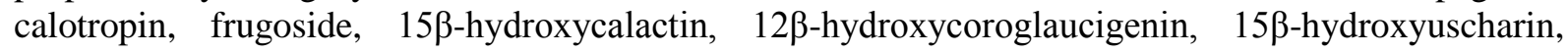
uscharidin, uscharin and uzarigenin are cardenolides reported in both species.

Table 1. Compounds reported in various plant parts of Calotropis species.

\begin{tabular}{|c|c|c|}
\hline Compound class and name & Plant part & Reference \\
\hline \multicolumn{3}{|l|}{ Calotropis gigantea } \\
\hline \multicolumn{3}{|l|}{ Oxypregnanes } \\
\hline Calotroposides A-G, S & Root, root bark & [20-23] \\
\hline Calotropone & Root & [24] \\
\hline \multicolumn{3}{|l|}{ Lignan derivatives } \\
\hline Medioresinol & Leaf & [25] \\
\hline Pinoresinol & Leaf & [25] \\
\hline \multicolumn{3}{|l|}{ Terpenes/terpenoids } \\
\hline$\beta$-Amyrin & Root & [20] \\
\hline Anhydrosophoradiol-3-acetate & Flower & [26] \\
\hline Drummondol & Leaf & [25] \\
\hline Lupeol & Root & [20] \\
\hline 24-Methylenecycloartenol & Root & [20] \\
\hline Taraxasterol & Root & [20] \\
\hline Taraxasteryl acetate & Leaf & [25] \\
\hline \multicolumn{3}{|l|}{ Sterols } \\
\hline (24R)-24-Ethylcholest-4-en-3-one & Leaf & [27] \\
\hline (24S)-24-Ethylcholest-4,22-dien-3-one & Leaf & [27] \\
\hline 6ß-Hydroxy-24-ethylcholest-4,22-dien-3-one & Leaf & [27] \\
\hline 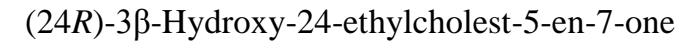 & Leaf & [27] \\
\hline$\beta$-Sitosterol & Root bark & [28] \\
\hline Stigmasterol & Root bark & [28] \\
\hline 3,5,8-Trihydroxy-24-methylcholest-6,22-diene & Leaf & [27] \\
\hline \multicolumn{3}{|l|}{ Cardenolides } \\
\hline $\begin{array}{l}3^{\prime}-O \text {-Acetylfrugoside } \\
\text { Afroside }\end{array}$ & $\begin{array}{l}\text { Bark } \\
\text { Latex, root bark }\end{array}$ & {$[30,31]$} \\
\hline $\begin{array}{l}\text { Atroside } \\
3^{\prime} \text {-epi-Afroside }\end{array}$ & Latex & [31] \\
\hline
\end{tabular}


Asclepin

3'-O-Benzoylfrugoside

Calactin

Calactinic acid

Calactinic acid ethyl ester

Calactinic acid methyl ester

Calotoxin

Calotropagenin

Calotropin

19-Carboxylcalactinic acid methyl ester

Coroglaucigenin

19-deoxy-15 $\beta$-Hydroxyuscharin

19-Dihydrocalactin

4 '- $\beta, 15 \beta$-Dihydroxycalactin

18,20-Epoxycalotropin

Frugoside

4 '- $\beta$-D-Glucofrugoside

$4^{\prime}-O-\beta-\mathrm{D}-\mathrm{Glucopyranosylfrugoside}$

Gofruside

Gomphoside

3'-epi-Gomphoside

19-nor-10-Hydrocalactinic acid methyl ester

$15 \beta$-Hydroxycalactin

$16 \alpha$-Hydroxycalactin

$15 \beta$-Hydroxycalactinic acid ethyl ester

$15 \beta$-Hydroxycalactinic acid methyl ester

$16 \alpha$-Hydroxycalactinic acid methyl ester

$15 \beta$-Hydroxycalotropin

16 $\alpha$-Hydroxycalotropin

$16 \alpha$-Hydroxycalotropagenin

$15 \beta$-Hydroxycardenolide

$12 \beta$-Hydroxycoroglaucigenin

$15 \beta$-Hydroxyuscharin

$16 \beta$-Hydroxyuscharin

3'-O-Methylcalotropin

2" -Oxovoruscharin

Uscharidin

Uscharin

2'-epi-Uscharin

Uzarigenin

Flavonoids

Isorhamnetin-3-O-glucopyranoside

Isorhamnetin-3- $O$ - $\alpha$-rhamnopyranosyl

$\left(1^{\prime \prime \prime} \rightarrow 6^{\prime \prime}\right)-\beta$-glucopyranoside

Isorhamnetin-3-O-rutinoside

\section{Miscellaneous}

Di-(2-ethylhexyl)phthalate

Calotropis procera

\section{Oxypregnanes}

Calotroposides H-N, S

Terpenes/terpenoids

$\alpha$-Amyrin acetate

Calotropenyl acetate

$\alpha$-Calotropeol

$\beta$-Calotropeol

Calotropoleanyl ester

Calotroprocerol A

Calotroproceryl acetates A, B

Calotroprocerone A

Calotropfriedelenyl acetate
Latex

Bark

Leaf, latex, root bark

Leaf

Root bark

[30]

Leaf, latex

Leaf, fruit, latex, root bark

Leaf, latex, root, root bark

[30-33]

Leaf, root, root bark

[30-34]

Latex

[31]

Root bark

[30]

Root bark [30]

Leaf [25]

Leaf, fruit, latex, root, root bark

Root

Root

Root

Latex

Latex

Leaf

Latex, root bark

[30,31]

Root bark

[30]

Root bark

t bark

Leaf, fruit, latex, root bark

$[25,30,31]$

$[31,32]$

Leaf

[30,31]

[31]

$[27,30,31,35]$

$[31,35]$

[25]

[36]

[36]

Flower 
Calotropterpenyl ester

Root bark

[46]

Calotropursenyl acetate

Root bark

1,2-Dihexadecanoyl-3-phosphatyl glycerol

Root

Dihydrophytoyl tetraglucoside

Root

$3 \beta, 27$-Dihydroxy-urs-18-en-13,28-olide

Latex

Latex

3-epi-Moreretenol

Multiflorenol

Latex

Phytyl iso-octyl ether

Latex

Procerasesterterpenoyl triglucoside

Root

Proceroleanenols A, B

Root

Pseudotaraxasterol acetate

Root bark

Taraxasterol

Urs-19(29)-en-3- $\beta$-ol

Root bark

Urs-19(29)-en-3-yl acetate

Latex, root bark

\section{Sterols}

$\beta$-Sitosterol

$\beta$-Sitosterol glucoside

Latex

Stigmasterol

\section{Cardenolides}

Afrogenin

Afroside

$\beta$-Anhydroepidigitoxigenin

Latex

Latex

Aerial part, roo

$\beta$-Anhydroepidigitoxigenin-3 $\beta-O$ -

Latex, root bark

Latex

Stem

glucopyranoside

Calactin

Stem

Calactoprocin

Calotoxin

Calotropagenin

Calotropin

Deglucouzarin

19-Dihydrocalotropagenin

Dihydrouscharin

Dihydrovoruscharin

Frugoside

$15 \beta$-Hydroxycalactin

$12 \beta$-Hydroxycoroglaucigenin

$15 \beta$-Hydroxyuscharin

Latex, aerial part

Latex

Latex, aerial part

Latex

Latex, root bark, aerial part

Stem

Latex, aerial part

Latex

Latex

Stem, root bark

Latex

Latex

Ischaridin

Latex

Aerial part

Ischarin

Aerial part

[42]

2"'Oxovoruscharin

Procegenins A, B

Root bark

[55]

Latex

[50]

Proceraside A

Root bark

Procerocid

Latex

Syriogenin

Latex

Uscharidin

Latex

Uscharin

Latex, aerial part

Uzarigenin

Uzarigenone

Uzarin

Stem, latex, aerial part

$[42,51,53,56]$

Stem

Stem

Voruscharin

Latex

Flavonoids

5-Hydroxy-3,7-dimethoxyflavone-4'-

$O$ - $\beta$-glucopyranoside

$3^{\prime}$ - $O$-Methyl quercetin-3- $O$-rutinoside

Stem

Aerial part

Miscellaneous

Root

Butanediol diglucuronoside

Methyl resorcinyl triglycoside 
Cardenolides are $\mathrm{C}_{23}$ steroids consisting of an unsaturated five-membered lactone ring with a double bond, which is attached to a steroid nucleus at C-17 and a sugar moiety at C-3 (Figure 2) [57]. The biosynthetic pathway of cardenolides involves cholesterol $\rightarrow 20 \alpha$-hydroxycholesterol $\rightarrow$ pregnenolone $\rightarrow$ progesterone $\rightarrow$ cardenolide [58]. They are a large group of compounds with considerable structural diversity and have long been used as drugs for treating congestive heart failures $[59,60]$. Recently, their roles in the treatment of cancer have been established as they can induce apoptosis and inhibit the growth of cancer cell lines. At low concentrations, cardenolides have cytoprotective effects by stimulating proliferation and inhibiting cell death in normal cells [59]. Phytochemical studies have revealed that cardenolides are involved in complex cell-signal transduction mechanisms, resulting in the selective control of human tumour but not the proliferation of normal cells [60]. Therefore, cardenolides are promising agents for targeted cancer chemotherapy.

Many genera of plants from the family Apocynaceae are known to contain cardenolides. Besides Calotropis, they are also distributed in Apocynum, Cerbera, Nerium, Strophanthus and Thevetia [61]. Almost 200 compounds of cardenolides have been isolated and identified from this family of which about $25 \%$ of them have been reported to possess anticancer activity.

\section{Cytotoxicity of Cardenolides}

\subsection{Calotropis gigantea}

Cardenolides isolated from the root bark of $C$. gigantea exhibited cytotoxic activity against A549 and HeLa human cancer cells [30]. Results of this study indicated the following structureactivity relationships:

i) Compounds with six-membered ring sugar groups (Figure 2) showed significantly stronger inhibitory activity, notably, 19-dihydrocalactin $\left(\mathrm{IC}_{50}=0.03\right.$ and $\left.0.05 \mu \mathrm{M}\right)$, calactin $\left(\mathrm{IC}_{50}=0.02\right.$ and $0.03 \mu \mathrm{M})$, calotoxin $\left(\mathrm{IC}_{50}=0.07\right.$ and $\left.0.09 \mu \mathrm{M}\right)$, and calotropin $\left(\mathrm{IC}_{50}=0.03\right.$ and $\left.0.05 \mu \mathrm{M}\right)$. Compounds with five-membered ring sugar groups such as $15 \beta$-hydroxycalactinic acid methyl ester, $15 \beta$-hydroxycalactinic acid ethyl ester and calactinic acid ethyl ester were inactive $\left(\mathrm{IC}_{50}>\right.$ $10 \mu \mathrm{M})$.

ii) A formyl $(\mathrm{CHO})$ or methyl-hydroxyl $\left(\mathrm{CH}_{2} \mathrm{OH}\right)$ group at $\mathrm{C}-10$ enhanced cytotoxicity of the compounds. $15 \beta$-Hydroxycalactin with a $\mathrm{CHO}$ group was much more cytotoxic than afroside which has a $\mathrm{CH}_{2}$ group. 19-Dihydrocalactin with a $\mathrm{CH}_{2} \mathrm{OH}$ group displayed similar potency as calactin with a $\mathrm{CHO}$ group.

iii) The presence of 4'-OH or 16-OH groups decreased cytotoxicity. Calotoxin with an $\mathrm{OH}$ group at C-4' is three times less effective than calactin. $16 \alpha$-Hydroxycalactin with an $\mathrm{OH}$ group at C-16 showed no cytotoxic activity.

Two new cardenolides along with 12 known compounds were isolated from the leaves of $C$. gigantea [25]. Seven of these compounds (18,20-epoxycalotropin, uzarigenin, calactin, calotropin, $15 \beta$-hydroxycalotropin, calactinic acid methyl ester and 19-carboxylcalactinic acid methyl ester) were evaluated for their cytotoxicity against KB, BC and NCI-H187 human cancer cell lines. Calactin was the most potent, whereas its 3 '-epimer, calotropin was less potent, indicating the importance of the stereochemistry at C-3'. Uzarigenin, with no sugar unit and only a hydroxyl group at C-3, was much weaker than calotropin [25]. The $\mathrm{IC}_{50}$ values of calactin, calotropin and uzarigenin were $0.04,0.06$ and $9.61 \mu \mathrm{M}$ against $\mathrm{KB}$ cells, $0.02,0.04$ and $8.95 \mu \mathrm{M}$ against $\mathrm{BC}$ cells, and $0.35,0.47$ and $9.77 \mu \mathrm{M}$ against NCI-H187 cells.

Among the cardenolides with similar sugar residues, the order of cytotoxic activity was calotropin $>15 \beta$-hydroxycalotropin $>18,20$-epoxycalotropin, suggesting that the $\gamma$-lactone moiety is crucial for their cytotoxic activity [30]. The steric effect of the $\mathrm{OH}$ group at $\mathrm{C}-15$ as in $15 \beta-$ hydroxycalotropin reduced cytotoxicity. When comparing calotropin and calactinic acid methyl ester with six- and five-membered ring sugar moieties, respectively, calotropin was more cytotoxic. The presence of a formyl group at C-10 gave enhanced cytotoxic effect. 


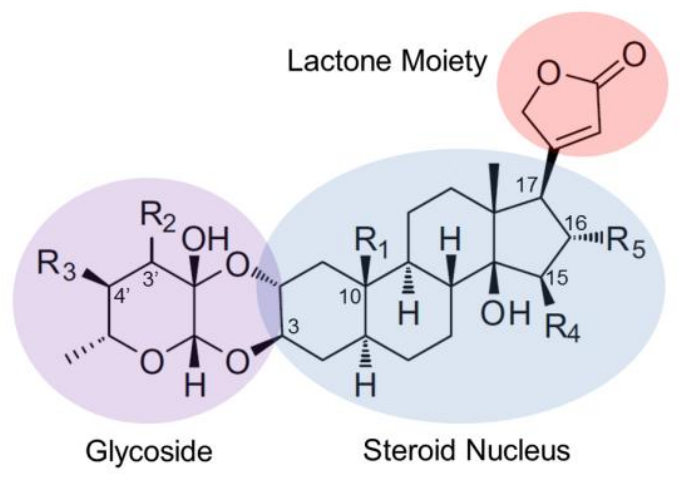

\begin{tabular}{|c|c|c|c|c|c|}
\hline Cardenolide & $R_{1}(C-10)$ & $\mathbf{R}_{2}\left(\mathrm{C}^{-3^{\prime}}\right)$ & $R_{3}\left(C-4^{\prime}\right)$ & $R_{4}(C-15)$ & $R_{5}(C-16)$ \\
\hline Calactin & $\mathrm{CHO}$ & $\beta-\mathrm{OH}$ & $\mathrm{H}$ & $\mathrm{H}$ & $\mathrm{H}$ \\
\hline Calotoxin & $\mathrm{CHO}$ & $\beta-\mathrm{OH}$ & $\mathrm{OH}$ & $\mathrm{H}$ & $\mathrm{H}$ \\
\hline Calotropin & $\mathrm{CHO}$ & $\alpha-\mathrm{OH}$ & $\mathrm{H}$ & $\mathrm{H}$ & $\mathrm{H}$ \\
\hline 19-Dihydrocalactin & $\mathrm{CH}_{2} \mathrm{OH}$ & $\beta-\mathrm{OH}$ & $\mathrm{H}$ & $\mathrm{H}$ & $\mathrm{H}$ \\
\hline $15 \beta$-Hydroxycalactin & $\mathrm{CHO}$ & $\beta-\mathrm{OH}$ & $\mathrm{H}$ & $\mathrm{OH}$ & $\mathrm{H}$ \\
\hline 16 $\alpha$-Hydroxycalactin & $\mathrm{CHO}$ & $\beta-\mathrm{OH}$ & $\mathrm{H}$ & $\mathrm{H}$ & $\mathrm{OH}$ \\
\hline $15 \beta$-Hydroxycalotropin & $\mathrm{CHO}$ & $\alpha-\mathrm{OH}$ & $\mathrm{H}$ & $\mathrm{OH}$ & $\mathrm{H}$ \\
\hline
\end{tabular}

Figure 2. Molecular structures of some cardenolides with six-membered ring sugar groups isolated from the root bark of Calotropis gigantea [30].

From the leaves of $C$. gigantea, 16 $\alpha$-hydroxycardenolide, calotropagenin, calotoxin, frugoside and 12 $\beta$-hydroxycoroglaucigenin showed cytotoxic activity against KB, MCF7 and NCI-H187 human cancer cells [32]. Calotoxin displayed strong activity against KB cells while frugoside had good overall activity. KB cells were the most susceptible and MCF7 cells the least susceptible. Concurrently, uscharin isolated from the leaves of $C$. gigantea has been reported to exhibit potent cytotoxicity towards A549, HCT116 and HepG2 cancer cells with $\mathrm{IC}_{50}$ values of $0.003,0.013$ and $0.018 \mu \mathrm{g} / \mathrm{mL}$, respectively [27].

From the roots of $C$. gigantea, coroglaucigenin, gofruside and frugoside showed cytotoxicity against K562 and SGC-7901 cancer cells [24,34]. IC 50 values were 4.7 and $14 \mu \mathrm{g} / \mathrm{mL}$ for both coroglaucigenin and gofruside, and 3.4 and $6.5 \mu \mathrm{g} / \mathrm{mL}$ for frugoside. Coroglaucigenin with an $\mathrm{OH}$ group at C-3 was less active than frugoside, suggesting that a sugar unit at C-3 was crucial for the cytotoxic activity. Earlier, cardenolides from the roots of $C$. gigantea were tested for cytoxicity against a panel of cancer cell lines of human and mouse origin [33]. At $2 \mu \mathrm{g} / \mathrm{mL}$, the compounds were cytotoxic to human cancer cells and not to mouse cancer cells. Against human cancer cells, calotropin exhibited the strongest activity followed by frugoside, 4'-O- $\beta$-D-glucopyranosyl frugoside and coroglaucigenin.

From the latex of $C$. gigantea, asclepin, calactin, calotropin, 15ß-hydroxyuscharin, 19-deoxy$15 \beta$-hydroxyuscharin, gomphoside, 2 "-oxovoruscharin and uscharin were tested for their cytotoxic effects on MCF7 breast cancer cells [31]. All eight cardenolides demonstrated strong cytotoxicity with $\mathrm{IC}_{50}$ values ranging from $30.5 \mathrm{nM}$ (asclepin) to $68.8 \mathrm{nM}$ (gomphoside). They were not toxic to MCF10A normal breast cells $\left(\mathrm{IC}_{50}\right.$ values $\left.>20 \mu \mathrm{M}\right)$.

\subsection{Calotropis procera}

The methanol, hexane, aqueous and ethyl acetate root extracts of $C$. procera were tested for cytotoxic activity against Hep2 cancer cells [62]. Results showed that the ethyl acetate root extract, known to be rich cardenolides, displayed the strongest cyctotoxic effect (96\%) after $48 \mathrm{~h}$ of treatment compared to the extracts of methanol $(73 \%)$ and hexane $(61 \%)$. The extract treated Hep2 cells exhibited typical morphological changes of apoptosis through cell cycle arrest at the $\mathrm{S}$ phase which prevented the cells from entering the G2/M phase. This indicated that cardenolides in the extracts can inhibit the proliferation of Hep2 cells via apoptosis and cell cycle disruption. Similarly, the methanol 
leaf extract $C$. procera has been shown to induce apoptosis and cell cycle arrest at G2/M phase in SKMEL-2 cells human skin melanoma [63].

Out of four cardenolides isolated from the stems of C. procera, only uzarigenin $(50 \mathrm{mM})$ was moderately cytotoxic towards human cancer cells of HT29 (59\%) and HepG2 (35\%) [50]. No inhibition of NIH-3T3 mouse fibroblast cells was observed. From the root bark of C. procera, proceraside A, frugoside and calotropin exhibited potent cytotoxic activity against A549, U373 and PC-3 cancer cells with $\mathrm{IC}_{50}$ values ranging from $0.01-0.30 \mu \mathrm{g} / \mathrm{mL}$ [51]. All three new cardenolides along with eight known ones isolated from the latex of $C$. procera displayed various degrees of cytotoxic activity [49]. Strongest activity was observed in calactin with $\mathrm{IC}_{50}$ values of 0.04 and 0.08 $\mu \mathrm{M}$ against A-549 and HeLa cells, respectively.

Chemical modification of 2"-oxovoruscharin, a novel cardenolide isolated from the root bark of $C$. procera, has led to the synthesis of UNBS1450, a compound characterized by more potent antiproliferative activity and lower toxicity $[55,64,65]$. The compound displayed anti-tumour activity against a panel of 57 human cancer cell lines that is comparable to taxol, and stronger than SN-38, two of the most potent drugs used in hospitals to treat cancer [55]. Against Hs683, U373, HCT-15, LoVo and $\mathrm{A} 549$, the $\mathrm{IC}_{50}$ values of UNBS1450 $(3,9,24,10$ and $8 \mathrm{nM})$ were superior to those of 2"oxovoruscharin $(8,15,16,10$ and $74 \mathrm{nM})$, respectively.

UNBS1450 markedly inhibited the viability and proliferation of human prostate cancer cell but not of normal cells [66]. This non-apoptotic cancer cell death mediated by nucleolar targeting and down-regulation of c-Myc expression is a new mechanism of anti-tumour action. Through disorganization of the actin cytoskeleton, the compound possesses both anti-proliferative and antimigratory properties $[55,64,65]$. UNBS1450 has shown to be a potent sodium pump inhibitor and induces non-apoptotic cell death. The compound induces apoptotic cell death in human leukemia cells at low concentrations [67]. It activates caspase-dependent apoptosis, suppresses the expression of Mcl1, activating pro-apoptotic Bak and Bax proteins and eventually leading to cell death via the mitochondrial apoptotic pathway [67,68]. UNBS1450 is currently in Phase I clinical trials.

\section{Non-cytotoxic Cardenolides}

While most cardenolides isolated from $C$. gigantea and $C$. procera displayed cytotoxic activity against human cancer cells, there are reports that some did not have activity against certain cell lines. A compilation of cardenolides that are inactive against cancer cell lines tested are listed in Table 2 as a guide for researchers.

Table 2. Cardenolides of Calotropis species that are inactive against cancer cell lines tested.

\begin{tabular}{|c|c|c|c|}
\hline Cardenolide & Plant part & Cancer cell line & Reference \\
\hline \multicolumn{4}{|l|}{ Calotropis gigantea } \\
\hline Afroside & Root bark & A549, HeLa & [30] \\
\hline Calactinic acid ethyl ester & Root bark & A549, HeLa & [31] \\
\hline 19-Carboxylcalactinic acid methyl ester & Leaf & KB, BC, NCI-H187 & [25] \\
\hline Coroglaucigenin & Root & $\begin{array}{l}\text { DLD-1, MKN-45, HepG2, } \\
\text { Hu H7, PC-9, OST, LNCap }\end{array}$ & [33] \\
\hline 4 '- $\beta, 15 \beta$-Dihydroxycalactin & Root bark & A549, HeLa & [30] \\
\hline $2 \alpha, 15 \beta$-Dihydroxy-19-oxo-uzarigenin & Leaf & KB, MCF7, NCI-H187 & [32] \\
\hline 16a-Hydroxycalactin & Root bark & A549, HeLa & [30] \\
\hline 15ß-Hydroxycalactinic acid & Leaf & KB, MCF7, NCI-H187 & [32] \\
\hline $15 \beta$-Hydroxycalactinic acid ethyl ester & Root bark & A549, HeLa & [30] \\
\hline $15 \beta$-Hydroxycalactinic acid methyl ester & Root bark & A549, HeLa & [30] \\
\hline 16 $\alpha$-Hydroxycalotropagenin & Leaf & KB, MCF7, NCI-H187 & [32] \\
\hline $15 \beta$-Hydroxycalotropin & Root bark & A549, HeLa & [30] \\
\hline \multicolumn{4}{|l|}{ Calotropis procera } \\
\hline$\beta$-Anhydroepidigitoxigenin & Stem & HT29, HepG2 & [51] \\
\hline$\beta$-Anhydroepidigitoxigenin-3 3 - $O$-glucopyranoside & Stem & HT29, HepG2 & [51] \\
\hline 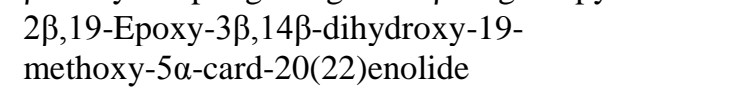 & Stem & HT29, HepG2 & [51] \\
\hline
\end{tabular}




\section{Cytotoxicity of Other Compounds}

It is important to note that, besides cardenolides, other compounds of $C$. gigantea and $C$. procera such as oxypregnanes also exhibit cytotoxic activities. Calotroposides from the root bark of $C$. gigantea have also been reported to possess cytotoxic activity against cancer cell lines [22]. Calotropone from the roots of $C$. gigantea was cytotoxic towards $\mathrm{K} 562$ cells with $\mathrm{IC}_{50}$ value of 9.2 $\mu \mathrm{g} / \mathrm{mL}$ [24]. From the root bark of $C$. procera, calotroposides K, M and S displayed the strong cytotoxic activity against A549, U373 and PC-3 cancer cells with $\mathrm{IC}_{50}$ values ranging from $0.5-4.4$, $0.5-4.5$ and $0.1-0.2 \mu \mathrm{M}$, respectively [38,39].

\section{Conclusion}

Although there are many reviews on $C$. gigantea and $C$. procera, this review is unique in that it focuses on the phytochemistry and cytotoxicity of cardenolides of these two species. Among the different classes of compounds isolated from $C$. gigantea and $C$. procera, the cardenolides are the most diverse and many have anticancer properties. Their roles in the treatment of human cancer have been established as they can induce apoptosis and inhibit the growth of cancer cells. In general, cardenolides with six-membered ring sugar groups have significantly stronger inhibitory activity than those with five-membered ring sugar groups. In this synopsis, a list of cardenolides from $C$. gigantea and $C$. procera that did not display any cytotoxic activity against certain cancer cell lines tested have been compiled as this information would serve as a useful guide for researchers. Chemical modification of 2"'-oxovoruscharin, a novel cardenolide isolated from the root bark of C. procera, has led to the synthesis of UNBS1450. The hemi-synthetic compound has more potent anti-proliferative activity, lower toxicity, and is a potent sodium pump inhibitor and inducer of non-apoptotic cell death. UNBS is currently in Phase I clinical trials. Besides cardenolides, other compounds of $C$. gigantea and C. procera such as oxypregnanes also exhibit cytotoxic activities.

\section{References}

[1] The Plant List. Calotropis. Available at http://www.theplantlist.org, 2013 [Accessed in Aug 2016].

[2] R. Kiew (2001). Calotropis. In: Plant resources of South-East Asia No. 12(2): Medicinal and poisonous plants 2, ed. J. L. C. H. Van Valkenburg and N. Bunyapraphatsara, Leiden, Netherlands, Backhuys Publisher.

[3] K. K. Mueen Ahmed, A. C. Rana and V. K. Dixit (2005). Calotropis species (Asclepiadaceae) - A comprehensive review, Pharmacogn. Mag. 1, 48-52.

[4] A. Kshirsagar, D. Ingawale, P. Ashok and N. Vyawahare (2009). Calotropis gigantea: A comprehensive review, Pharmacol. Online 2, 229-239.

[5] M. Kadiyala, S. Ponnusankar and K. Elango (2013). Calotropis gigantiea (L.) R. Br. (Apocynaceae): A phytochemical and pharmacological review, J. Ethnopharmacol. 150, 32-50.

[6] P. S. Kumar, E. Suresh and S. Kalavathy (2013). Review on a potential herb Calotropis gigantea (L.) R. Br., Sch. Acad. J. Pharm. 2, 135-143.

[7] S. Sarkar, R. Chakraverty and A. Ghosh (2014). Calotropis gigantea Linn. - A complete basket of Indian traditional medicine, Int. J. Pharm. Res. Sci. 2, 7-17.

[8] A. Mushir, N. Jahan and A. Ahmed (2016). A review on phytochemical and biological properties of Calotropis gigantea (Linn.) R. Br., Discov. Phytomed. 3, 15-21.

[9] A. K. Meena, A. K. Yadav, U. S. Niranjan, B. Singh, A. K. Nagariya, K. Sharma, A. Gaurav, S. Sharma and M. M. Rao (2010). A review on Calotropis procera Linn and its ethnobotany, phytochemical, pharmacological profile, Drug Invent. Today. 2, 185-190.

[10] S. Gupta, B. Gupta, K. Kapoor and P. Sharma (2012). Ethnopharmacological potential of Calotropis procera: An overview, Int. Res. J. Pharm. 3, 19-22.

[11] A. K. Khairnar, S. R. Bhamare and H. P. Bhamare (2012). Calotropis procera: An ethnopharmacological update, Adv. Res. Pharm. Biol. 2, 142-156.

[12] P. M. Ranjit, G. E. Rao, M. Krishnapriya, V. Nagalakshmi, P. Silpa and M. Anjali (2012). An overview of phytochemical and pharmacological activities of Calotropis procera, FS J. Pharm. Res. 1, 18-25.

[13] S. Quazi, K. Mathur and S. Arora (2013). Calotropis procera: An overview of its phytochemistry and pharmacology, Indian J. Drugs 1, 63-69.

[14] H. Oloumi (2014). Phytochemistry and ethno-pharmaceutics of Calotropis procera, Ethno-Pharm Prod. 1, $1-8$. 
[15] R. K. Upadhyay (2014). Ethnomedicinal, pharmaceutical and pesticidal uses of Calotropis procera (Aiton) (Family: Asclepiadaceae), Int. J. Green Pharm. 8, 135-146.

[16] E. A. Al-Snafi (2015). The constituents and pharmacological properties of Calotropis procera - An overview, Int. J. Pharm. Rev. Res. 5, 259-275.

[17] G. Parihar and N. Balekar (2016). Calotropis procera: A phytochemical and pharmacological review, Thai J. Pharm. Sci. 40, 115-131.

[18] B. Yogi, S. K. Gupta and A. Mishra (2016). Calotropis procera (Madar): A medicinal plant of various therapeutic uses - A review, Bull. Env. Pharmacol. Life Sci. 5, 74-81.

[19] R. Verma, G. P. Satsangi and J. N. Shrivastava (2010). Ethno-medicinal profile of different plant parts of Calotropis procera (Ait.) R. Br., Ethnobot. Leaflets 14, 721-742.

[20] I. Kitagawa, R. Zhang, J. D. Park, N. I. Baek, Y. Takeda, M. Yoshikawa and H. Shibuya (1992). Indonesian medicinal plants I. Chemical structures of calotroposides A and B, two new oxypregnaneoligoglycosides from the root of Calotropis gigantea (Asclepiadaceae), Chem. Pharm. Bull. 40, 2007-2013.

[21] H. Shibuya, R. Zhang, J. D. Park, N. I. Baek, Y. Takeda, M. Yoshikawa and I. Kitagawa (1992). Indonesian medicinal plants. V. Chemical structures of calotroposides C, D, E, F and G, five additional new oxypregnane-oligoglycosides from the roots of Calotropis gigantea (Asclepiadaceae), Chem. Pharm. Bull. 40, 2647-2653.

[22] R. Mahar, S. Dixit, T. Joshi, S. Kanojiya, D. K. Mishra, R. Konwar and S. K. Shukla (2016). Bioactivity guided isolation of oxypregnane-oligoglycosides (calotroposides) from the root bark of Calotropis gigantea as potent anticancer agents, RSC Adv. 6, 104215-104226.

[23] S. R. M. Ibrahim, G. A. Mohamed, L. A. Shaala and D. T. A. Youssef (2016). Calotroposide S, new oxypregnane oligoglycoside from Calotropis procera Root Bark, Rec. Nat. Prod. 10,761-765.

[24] Z. N. Wang, M. Y. Wang, W. L. Mei, Z. Han and H. F. Dai (2008). A new cytotoxic pregnanone from Calotropis gigantea, Molecules 13, 3033-3039.

[25] T. Lhinhatrakool and S. Sutthivaiyakit (2006). 19-Nor- and 18,20-epoxy-cardenolides from the leaves of Calotropis gigantea, J. Nat. Prod. 69, 1249-1251.

[26] M. R. Habib, M. A. Islam and M. R. Karim (2013). Cytotoxic chemicals from Calotropis gigantea flower, Chem. Nat. Compd. 49, 165-166.

[27] S. D. Jacinto, E. A. Chun, A. S. Montuno, C. C. Shen, D. L. Espineli and C. Y. Ragasa (2011). Cytotoxic cardenolide and sterols from Calotropis gigantea, Nat. Prod. Commun. 6, 803-806.

[28] M. R. Habib, F. Nikkon, M. Rahman, M. E. Haque and M. R. Karim (2007). Isolation of stigmasterol and $\beta$-sitosterol from methanolic extract of root bark of Caloptropis gigantea (Linn.), Pak. J. Biol. Sci. 10, 4174-4176.

[29] P. V. Khang, Z. G. Zhang, Y. Meng, D. Guo, X. Liu, L. H. Hu and L. Ma (2014). Cardenolides from the bark of Calotropis gigantea, Nat. Prod. Res. 28, 1191-1196.

[30] H. You, M. Lei, W. Song, H. Chen, Y. Meng, D. Guo, X. Liu and L. H. Hu (2013). Cytotoxic cardenolides from the root bark of Calotropis gigantea, Steroids 78, 1029-1034.

[31] S. Parhira, G. Y. Zhu, M. Chen, L. P. Bai and Z. H. Jiang (2016). Cardenolides from Calotropis gigantea as potent inhibitors of hypoxia-inducible factor-1 transcriptional activity, J. Ethnopharmacol. 194, 930-936.

[32] C. Seeka and S. Sutthivaiyakit (2010). Cytotoxic cardenolides from the leaves of Calotropis gigantea, Chem. Pharm. Bull. 58, 725-728.

[33] F. Kiuchi, Y. Fukao, T. Maruyama, T. Obata, M. Tanaka, T. Sasaki, M. Mikage, M. E. Haque and Y. Tsuda (1998). Cytotoxic principles of a Bangladeshi crude drug, akond mul (roots of Calotropis gigantea L.), Chem. Pharm. Bull. 46, 528-530.

[34] M. Y. Wang, W. L. Mei, Y. Y. Deng, S. L. Liu, Z. N. Wang and H. F. Dai (2008). Cytotoxic cardenolides from the roots of Calotropis gigantea, Modern Pharm. Res. 1, 4-9.

[35] S. Parhira, G. Y. Zhu, R. W. Jiang, L. Liu, L. P. Bai and Z. H. Jiang (2014). 2'-epi-Uscharin from the latex of Calotropis gigantea with HIF-1 inhibitory activity, Sci. Rep. 4, 4748, DOI: 10.1038/srep04748.

[36] S. Sen, N. P. Sahu and S. B. Mahato (1992). Flavonol glycosides from Calotropis gigantea, Phytochemistry 31, 2919-2921.

[37] V. K. Agrawal, N. Ganesh and S. J. Chundattu (2010). Isolation of isorhamnetin-3-O- $\alpha-$ rhamno pyranosyl(1"" $\rightarrow 6 ")-\beta$-glucopyranoside from Calotropis gigantea, Nat. Prod. Med. 3, 84-86.

[38] S. R. M. Ibrahim, G. A. Mohamed, L. A. Shaala, L. M. Y. Banuls, R. Kiss and D. T. A. Youssef (2015). Calotroposides H-N, new cytotoxic oxypregnane oligoglycosides from the root bark of Calotropis procera, Steroids $\mathbf{9 6}, 63-72$.

[39] S. R. M. Ibrahim, G. A. Mohamed, L. A. Shaala and D. T. A. Youssef (2016). Calotroposide S, new oxypregnane oligoglycoside from Calotropis procera root bark, Rec. Nat. Prod. 10, 761-765. 
[40] A. Mittal and M. Ali (2012). Aliphatic and phenolic glycosides from the roots of Calotropis procera (Ait.) R. Br., Int. J. PharmTech Res. 4, 213-217.

[41] A. Q. Khan, Z. Ahmed, S. N. Kazmi and A. Malik (1988). A new pentacyclic triterpene from Calotropis procera, J. Nat. Prod. 51, 925-928.

[42] N. I. Sweidan and M. H. Abu Zarga (2015). Two novel cardenolides from Calotropis procera, J. Asian Nat. Prod. Res. 17, 900-907.

[43] R. Pant and K. Chaturvedi (1989). Chemical analysis of Calotropis procera latex, Curr. Sci. 58, 740742.

[44] S. H. Ansari and M. Ali (2000). New oleanene triterpenes from root bark of Calotropis procera (Ait.) R. Br., Indian J. Chem. 39, 287-290.

[45] S. R. M. Ibrahim, G. A. Mohamed, L. A. Shaala, L. M. Banuls, G. Van Goietsenoven, R. Kiss and D. T. A. Youssef (2012). New ursane-type triterpenes from the root bark of Calotropis procera, Phytochem. Lett. 5, 490-495.

[46] S. H. Ansari and M. Ali (2001). Norditerpenic ester and pentacyclic triterpenoids from the root bark of Calotropis procera (Ait) R. Br., Die Pharm. 56, 175-177.

[47] F. Brüschweiler, W. Stöcklin, K. Atöckel and T. Reichstein (1969). Glycosides of Calotropis procera R. Br., Helv. Chem. Acta 52, 2086-2106.

[48] S. J. Chundattu, V. K. Agrawal and N. Ganesh (2016). Phytochemical investigation of Calotropis procera, Arab. J. Chem. 9, S230-S234.

[49] A. Mittal and M. Ali (2015). Acyclic diterpenic constituents from the roots of Calotropis procera (Ait.) R. Br., J. Saudi Chem. Soc. 19, 59-63.

[50] N. H. Mohamed, M. Liu, W. M. Abdel-Mageed, L. H. Alwahibi, H. Dai, M. A. Ismail, G. Badr, R. J. Quinn, X. Liu, L. Zhang and A. A. M. Shoreit (2015). Cytotoxic cardenolides from the latex of Calotropis procera, Bioorg. Med. Chem. Lett. 25, 4615-4620.

[51] K. H. Shaker, N. Morsy, H. Zinecker, J. F. Imhoff and B. Schneider (2010). Secondary metabolites from Calotropis procera (Aiton), Phytochem. Lett. 3, 212-216.

[52] S. R. M. Ibrahim, G. A. Mohamed, L. A. Shaala, L. Moreno, Y. Banuls, R. Kiss and D. T. A. Youssef (2014). Proceraside A, a new cardiac glycoside from the root barks of Calotropis procera with in vitro anticancer effects, Nat. Prod. Res. 28, 1322-1327.

[53] M. H. A. Elgamal, A. G. Hanna, N. A. M. Morsy, H. Duddeck, A. Simon, T. Gáti and G. Tóth (1999). Complete $1 \mathrm{H}$ and $13 \mathrm{C}$ signal assignments of $5 \alpha$-cardenolides isolated from Calotropis procera $\mathrm{R}$. Br., J. Mol. Struct. 477, 201-208.

[54] M. A. Desheesh, H. M. Youssef, M. A. El-Sebaii, H. M. Sabry, S. I. Kassem and S. T. El-Deeb (2004). Glycosidic cardenolides. Histopathological symptoms of cardenolides effects on different organs from white Norway rats (Rattus norvegicus var. albus), Alexandria Sci. Exc. 25, 655-669.

[55] E. Van Quaquebeke, G. Simon, A. Andre, J. Dewelle, M. El Yazidi, F. Bruyneel, J. Tuti, O. Nacoulma, P. Guissou, C. Decaestecker, J. C. Braekman, R. Kiss and F. Darro (2005). Identification of a novel cardenolide (2"-oxovoruscharin) from Calotropis procera and the hemisynthesis of novel derivatives displaying potent in vitro anti-tumour activities and high in vivo tolerance: structure-activity relationship analyses, J. Med. Chem. 48, 849-856.

[56] A. G. Hanna, M. H. A. Elgamal, N. A. M. Morsy, H. Duddeck, J. Kovács and G. Tóth (1999). Two cardenolides from Calotropis procera, Magn. Reson. Chem. 37, 754-757.

[57] T. Mijatovic, E. Van Quaquebeke, B. Delest, O. Debeir, F. Darro and R. Kiss (2007). R. Cardiotonic steroids on the road to anti-cancer therapy, Biochim. Biophy. Acta. 1776, 32-57.

[58] J. A. F. Wickramasinghe, P. C. Hirsch, S. M. Munavalli and E. Caspi (1968). Biosynthesis of plant sterols. VII. The possible operation of several routes in the biosynthesis of cardenolides from cholesterol, Biochemistry 7, 3248-3253.

[59] I. Prassas and E. P. Diamandis (2008). Novel therapeutic applications of cardiac glycosides, Nat. Rev. Drug Discov. 7, 926-935.

[60] R. A. Newman, P. Yang, A. D. Pawlus and K. I. Block (2008). Cardiac glycosides as novel cancer therapeutic agents, Mol. Interv. 8, 26-49.

[61] S. Wen, Y. Chen, Y. Lu, Y. Wang, L. Ding and M. Jiang (2016). Cardenolides from the Apocynaceae family and their anticancer activity, Fitoterapia 112, 74-84.

[62] R. Mathur, S. K. Gupta, S. R. Mathur and T. Velpandian (2009). Anti-tumour studies with extracts of Calotropis procera (Ait.) R. Br. roots employing Hep2 cells and possible mechanism of action, Indian J. Exper. Biol. 47, 343-348.

[63] A. L. Joshi, P. H. Roham, R. Mhaske, M. Jadhav, K. Krishnadas, A. Kharat, B. Hardikar and K. R. Kharat (2015). Calotropis procera extract induces apoptosis and cell cycle arrest at G2/M phase in human skin melanoma (SK-MEL-2) cells, Nat. Prod. Res. 29, 2261-2264. 
[64] T. Mijatovic, F. Lefranc, E. Van Quaquebeke, F. Van Vynckt, F. Darro and R. Kiss (2007). UNBS1450: A new hemi-synthetic cardenolide with promising anti-cancer activity, Drug Dev. Res. 68, 164-173.

[65] T. Juncker, M. Schumacher, M. Dicato and M. Diederich (2009). UNBS1450 from Calotropis procera as a regulator of signaling pathways involved in proliferation and cell death, Biochem. Pharmacol. 78, 1-10.

[66] T. Mijatovic, N. De Nève, P. Gailly, V. Mathieu, B. Haibe-Kains, G. Bontempi, J. Lapeira, C. Decaestecker, V. Facchini and R. Kiss (2008). Nucleolus and c-Myc: Potential targets of cardenolidemediated anti-tumour activity, Mol. Cancer Ther. 7, 1285-1296.

[67] T. Juncker, C. Cerella, M. H. Teiten, F. Morceau, M. Schumacher, J. Ghelfi, F. Gaascht, M. Schnekenburger, E. Henry, M. Dicato and M. Diederich (2011). UNBS1450, a steroid cardiac glycoside inducing apoptotic cell death in human leukemia cells, Biochem. Pharmacol. 81, 13-23.

[68] C. Cerella, F. Muller, A. Gaigneaux, F. Radogna, E. Viry, S. Chateauvieux, M. Dicato and M. Diederich (2015). Early downregulation of Mcl-1 regulates apoptosis triggered by cardiac glycoside UNBS1450, Cell Death Dis. 6, e1782, DOI:10.1038/cddis.2015.134.

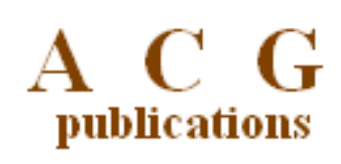

(C) 2017 ACG Publications 